\title{
Do Workplace Characteristics Moderate the Effects of Attitudes on Father Warmth and Engagement?
}

\author{
Erin Kramer Holmes \\ Brigham Young University - Provo, erin_holmes@byu.edu \\ Richard J. Petts \\ Ball State University \\ Clare R. Thomas \\ Brigham Young University - Provo \\ Nathan L. Robbins \\ Cornell University \\ Tom Henry

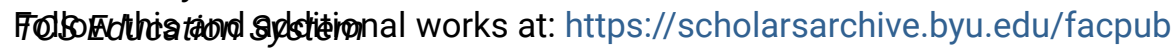 \\ Part of the Other Social and Behavioral Sciences Commons
}

\section{Original Publication Citation}

Holmes, E. K., Petts, R. J., *Thomas, C., *Robbins, N. L., and *Henry, T. (2020). Do workplace characteristics moderate the effects of attitudes on father warmth and engagement? Journal of Family Psychology. Advance Online Publication.

\section{BYU ScholarsArchive Citation}

Holmes, Erin Kramer; Petts, Richard J.; Thomas, Clare R.; Robbins, Nathan L.; and Henry, Tom, "Do Workplace Characteristics Moderate the Effects of Attitudes on Father Warmth and Engagement?" (2020). Faculty Publications. 4783.

https://scholarsarchive.byu.edu/facpub/4783

This Peer-Reviewed Article is brought to you for free and open access by BYU ScholarsArchive. It has been accepted for inclusion in Faculty Publications by an authorized administrator of BYU ScholarsArchive. For more information, please contact ellen_amatangelo@byu.edu. 


\title{
Do Workplace Characteristics Moderate the Effects of Attitudes on Father Warmth and Engagement?
}

\author{
Erin Kramer Holmes \\ Brigham Young University \\ Clare R. Thomas \\ Brigham Young University
}

\author{
Richard J. Petts \\ Ball State University \\ Nathan L. Robbins \\ Cornell University
}

\author{
Tom Henry \\ TCS Education System, Morton Grove, Illinois
}

\begin{abstract}
Though many fathers want to be warmer, more nurturing, and more actively involved than prior generations (i.e., the new fatherhood ideal), they also embrace a father's traditional role as financial earner. Thus, we hypothesized that fathers' attitudes about their roles would likely interact with workplace characteristics to produce variations in father warmth and engagement. Using a national sample of 1,020 employed U.S. fathers with children ages 2-8 years old, results suggest that adherence to the new fatherhood ideal was associated with more frequent father engagement and warmth, while endorsing traditional gender norms was associated with less father warmth. Also consistent with prior research showing that family friendly work cultures may enable fathers to be more engaged parents, we find that a family supportive workplace and greater flexibility in when and where fathers work, were associated with more frequent father engagement and warmth. Moreover, interaction results suggest that the associations between job flexibility and engagement are stronger for fathers who do not fully endorse the new fatherhood ideal; associations between workplace support and warmth are also stronger for fathers who do not fully endorse the new fatherhood ideal. Thus, flexibility and a family supportive workplace may particularly enable father involvement for fathers whose attitudes might otherwise be a barrier to their involvement.
\end{abstract}

Keywords: fathers, gender, workplace flexibility, work-life conflict, work-family interface

Supplemental materials: http://dx.doi.org/10.1037/fam0000672.supp

Today's fathers want to spend more time connecting with their children than fathers in prior generations (McGill, 2014); perhaps because fathers are becoming aware that warm, engaged fathering matters for child development (Pleck, 2010). For example, positive father involvement has been associated with infant attachment security (Brown, Mangelsdorf, \& Neff, 2012), toddlers' ability to regulate negative affect (Davidov \& Grusec, 2006), reduced behavior problems from infancy into middle childhood (Flouri, Mid-

This article was published Online First May 14, 2020.

(D) Erin Kramer Holmes, School of Family Life, Brigham Young University; (D) Richard J. Petts, Department of Sociology, Ball State University; Clare R. Thomas, School of Family Life, Brigham Young University; (D) Nathan L. Robbins, Policy Analysis and Management, Cornell University; Tom Henry, TCS Education System, Morton Grove, Illinois.

Preliminary analyses for this article were presented at the Work and Family Researchers Network Conference in Washington, DC.

Correspondence concerning this article should be addressed to Erin Kramer Holmes, School of Family Life, Brigham Young University, 2086 JFSB, Provo, UT 84602. E-mail: erin_holmes@byu.edu ouhas, \& Narayanan, 2016), and improved school achievement in the teen years (Ramirez-Valles, Zimmerman, \& Juarez, 2002).

Men may further desire more time with their families because men also benefit from positive involvement (Eggebeen, Knoester, \& McDaniel, 2012). Involved fathers say that becoming fathers has improved their lives (Palkovitz, Copes, \& Woolfolk, 2001). Though the direction of effects is less clear, they report greater job enhancements, fewer job strains (Graves, Ohlott, \& Ruderman, 2007), and stronger intergenerational connections (Eggebeen et al., 2012).

There is evidence that fathers' gender role attitudes, and perceptions of the role of the father in child development (also referred to as "the new fatherhood ideal"), each contribute to variations in father involvement (Petts, Shafer, \& Essig, 2018). Though many fathers want to be warm and actively involved, they also still embrace a father's traditional role as the main financial earner for his family (Kuo, Volling, \& Gonzalez, 2018). Thus, fathers may feel torn between the potentially competing demands of breadwinning and actively involved fathering. Indeed, reports from the National Study of the Changing Workforce suggest that work-family conflict increased among men in the United States 
over the past 30 years (Aumann, Galinsky, \& Matos, 2011). As such, some fathers may choose to emphasize either involved fathering or breadwinning to manage their work-family lives.

Further, workplace characteristics may facilitate-or hinderfather involvement. For example, some fathers may not be as involved as they desire due to lack of workplace support, lack of flexibility, or increasing work-to-family conflict; whereas fathers who have supportive employers, access to flexible work hours, or reduced work-to-family conflict may be able to be more involved with their children (for a review, see Behson, Holmes, Hill, \& Robbins, 2018).

Systemic ecological models of father involvement (Cabrera, Fitzgerald, Bradley, \& Roggman, 2014; Holmes \& Huston, 2010) and of the work-family interface (Voydanoff, 2004) suggest that a father's attitudes (both gender role attitudes and perceptions of the new fatherhood ideal) may also interact with workplace characteristics to predict his involvement with his child(ren). Though fathers who endorse egalitarian gender roles, or who adhere to new fatherhood ideals, may prioritize involvement with children regardless of their workplace environment, workplace characteristics may enable involvement for traditional fathers, or for fathers less fully endorse the new fatherhood ideal. Unfortunately, little research has considered interactions between workplace characteristics and men's gender role and fathering attitudes.

To address this gap, we explore fathers' gender role attitudes, adherence to the new fatherhood ideal, job flexibility, family supportive workplace, and work-to-family conflict, as they relate to engagement and warmth in fathers of young children (ages 2-8 years). Because fathering is positively associated with child and adolescent well-being (Brotherson, Yamamoto, \& Acock, 2003; Day \& Padilla-Walker, 2009; Flouri et al., 2016), and fathers' own well-being (Eggebeen et al., 2012) we seek to understand what facilitates or hinders involvement.

\section{Literature Review}

\section{A Systemic Ecological Approach to Studying Father Involvement}

Based on a systemic ecological perspective, scholars argue that many inter- and intrafamilial factors impact father involvement (Cabrera et al., 2014; Holmes, Baumgartner, Marks, Palkovitz, \& Nesteruk, 2010; Holmes \& Huston, 2010). A key proposition in this framework is that individuals are best understood in context. Thus, a father's individual behavior not only varies according to his personal characteristics (such as his attitudes about his gendered roles or his endorsement of the new fatherhood ideal), but also to the complex system of structures surrounding him (such as workplace policies and practices).

To explore the workplace as a context for fathering we refer to Voydanoff's (2004) systemic ecological theory on the workfamily interface. In her model, work and family represent distinct microsystems, with each being composed of roles, norms, and shared activities. When boundaries between family life and work life are permeable, each microsystem is more likely to influence the other, either through resources or through demands. Resources create a beneficial interplay between work and family. For example, support from a supervisor or job flexibility may facilitate a father's efforts to be warm or engaged. Conversely, demands such as work-family conflict may make it more challenging to be an engaged or warm father.

Just as systemic theories emphasize both the additive and interactive nature of father involvement (Cabrera et al., 2014; Holmes \& Huston, 2010), Voydanoff's (2004) theory also suggests interactions between personal and workplace characteristics. Unfortunately, few have explored interactions between a fathers' attitudes and workplace characteristics. In the present study, we use a systemic ecological theory to test the additive and interactive ways in which a father's traditional versus egalitarian views about gender, and his endorsement of the new fatherhood ideal, independently interact with job flexibility, a family supportive workplace, and work-family conflict to impact father engagement and father warmth (see Figure 1).

\section{Father Involvement}

Father involvement is a multidimensional construct that consists of engagement, warmth, responsibility, and indirect care-although scholars have focused on engagement and warmth more frequently than other aspects of involvement (Pleck, 2010). Fathers must spend quality time with their children for children to receive the maximum benefits from this involvement (Veneziano, 2003). This includes being engaged and alert during conversations or playtime (Flouri et al., 2016), as well as showing genuine warmth (Dyer, Day, \& Harper, 2014). It is important to consider factors that may enable fathers to spend more devoted time with their children.

\section{Traditional Gender Roles, the New Fatherhood Ideal, and Father Involvement}

The role of the father has been changing, largely encouraging fathers to be more emotionally responsible (Kuo et al., 2018) and more actively engaged in their children's lives (Marsiglio \& Roy, 2012). These changes have been termed "the new fatherhood ideal" (Petts et al., 2018). Despite these changes, many fathers find themselves trapped between traditional gendered norms and more modern ideals of fatherhood (McLaughlin \& Muldoon, 2014), or feel socially unequipped for parenting because mothers have traditionally been more involved in child rearing (McKelley \& Rochlen, 2016). Although fathers may wish to attain an ideal fatherhood status of equal parenting while managing work, many potential barriers exist.

Traditional beliefs about gendered roles present a potential barrier to father involvement. Men who endorse traditional attitudes are less engaged than egalitarian fathers (Holmes \& Huston, 2010; Petts et al., 2018; Riina \& Feinberg, 2012). In contrast, endorsement of the new father ideal may facilitate involvement. Men who believe fathers should nurture children are warmer and more engaged than those who believe mothering is more important for children's development (McGill, 2014; Petts et al., 2018). As such, fathers' attitudes about gender roles and their endorsement of the new fatherhood ideal are important correlates of father involvement. Based on a systemic ecological approach, we hypothesize:

H1: Traditional gender role norms will be negatively associated with engagement; endorsement of the new fatherhood ideal will be positively associated with engagement. 


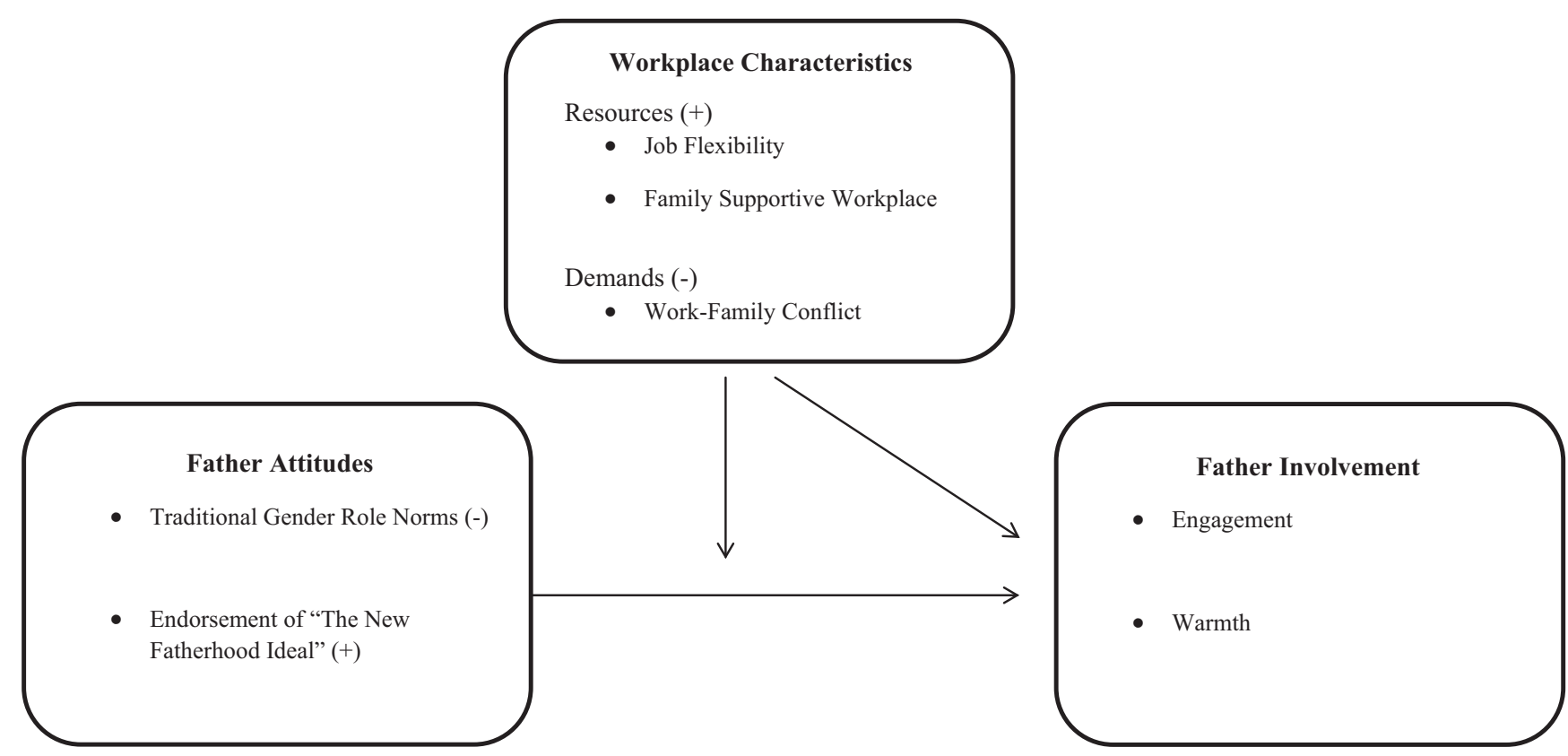

Figure 1. The direct and interactive effects of fathers' attitudes and workplace characteristics on father involvement. This model assumes direct effects of father attitudes and workplace characteristics on father involvement, and further assumes interaction between father attitudes and workplace characteristics on father involvement.

H2: Traditional gender role norms will be negatively associated with warmth; endorsement of the new fatherhood ideal will be positively associated with warmth.

\section{The Workplace and Father Involvement}

Consistent with our theory, in addition to fathering attitudes, employment may be a barrier to father involvement. Fathers find themselves juggling time between work and family, with many seeing themselves as employees first and fathers second (Burnett, Gatrell, Cooper, \& Sparrow, 2013). This conceptualization is supported by workplace culture, as male CEO's view employment as optional for women, but necessary for men (Tracy \& Rivera, 2010). Thus, fathers may fulfill the provider role at the cost of spending time with their children (Kuo et al., 2018).

However, as Voydanoff's (2004) model suggests, resources such as flexible work hours or a family supportive workplace environment could be a solution to work-family dilemmas (Dolcos \& Daley, 2009; Tracy \& Rivera, 2010). Workplace flexibility is a worker's capacity to choose when, where, and for how long they do work-related tasks (Hill \& Holmes, 2018). One of the most established findings in this literature is that workplace flexibility reduces work-family conflict (Allen, Johnson, Kiburz, \& Shockley, 2013; Hill, Erickson, Holmes, \& Ferris, 2010). Despite some important research demonstrating that fathers are more likely to use workplace programs such as flexibility that do not reduce their pay (compared with parental leaves or reduced work hours that would reduce pay; Aumann et al., 2011), flexibility is less commonly studied as a predictor of father involvement (Behson et al., 2018). This may be due to assumptions that mothers, not fathers, require workplace sup- ports to better attend to children's needs (Behson et al., 2018). We contribute to the literature by testing whether workplace flexibility will enable fathers to be warmer and more engaged with their young children.

Despite the benefits of flexibility, some employees choose not to use workplace flexibility, even when offered, out of fear of being stigmatized, considered lazy, or deemed uncommitted (Allen, 2001; Munsch, 2016; Williams, Blair-Loy, \& Berdahl, 2013). The presence of stigma or negative perceptions associated with using workplace programs suggests that a family supportive workplace may also help provide a bridge for fathers to better solve contemporary work family dilemmas (Kossek, Pichler, Bodner, \& Hammer, 2011). One meta-analysis suggests that a family friendly work culture reduces work-family conflict more than the other work characteristics explored in their study (i.e., flexibility of work location and schedule, dependent care availability and satisfaction, supervisor support, and coworker support; Mesmer-Magnus \& Viswesvaran, 2006). Thus, it appears that a family supportive workplace may also be an important resource that could promote father engagement and warmth.

Finally, much of the conversation surrounding the work-family interface is focused on how resources and demands affect workfamily conflict, with the implication that reducing work-family conflict will likely enhance parents' and children's lives (Voydanoff, 2004). Indeed, work-family conflict has been linked with child health (Ohu et al., 2019), parent mental health (Moreira, Fonseca, Caiado, \& Canavarro, 2019), and parenting stress (Nomaguchi \& Johnson, 2016). Surprisingly, fewer studies have explored associations between work-family conflict and father involvement. Those that have explored this link have found that higher work- 
family conflict was associated with father irritability and inconsistent parenting (Cooklin et al., 2016). Thus, we expand the current literature on work-family conflict by exploring how workfamily conflict may impact father warmth and engagement. We hypothesize:

H3: Three workplace characteristics will be associated with father engagement. The resources of job flexibility, and a family supportive workplace, will increase father engagement, whereas the demand of work-family conflict will reduce father engagement.

H4: These workplace characteristics will also be associated with father warmth such that job flexibility and a family supportive workplace will increase father warmth, whereas work-family conflict will reduce father warmth.

\section{Interaction Between Father Attitudes, Workplace Environments, and Father Involvement}

A systemic ecological theory suggests that father attitudes and workplace characteristics are independently and interactively associated with father involvement (Cabrera et al., 2014; Holmes et al., 2010; Holmes \& Huston, 2010). A father's endorsement of gendered expectations about his role (i.e., whether he endorses more traditional or egalitarian attitudes), or how much he embraces the new fatherhood ideal will each likely interact with work characteristics to influence involvement.

Our theory and prior research suggest a few possible directions for these interactions. On one hand, access to resources such as flexibility or working in a family supportive environment may be especially beneficial to egalitarian fathers, and to fathers who endorse the new fatherhood ideal. They may embrace supportive workplace programs, and/or perhaps seek out family friendly workplaces, to maintain the fathering they desire (Petts \& Knoester, 2018). In these instances, we may see even greater effects on father engagement and father warmth.

On the other hand, fathers who endorse the new fatherhood ideal or who have an egalitarian gender ideology may be highly engaged and warm toward their children regardless of their work environment (Petts et al., 2018). In contrast, access to more work resources and reduced work demands may encourage traditional fathers to be more engaged or warmer in their children's lives, even if they were not intending to do so. As such, workplace characteristics may provide the structure and motivation that more traditional fathers need to increase their involvement. Thus, we further hypothesize that:

H5: A father's engagement will vary as a function of the interaction between his fathering attitudes (i.e., gender role norms, or endorsement of the new fatherhood ideal) and his work characteristics (job flexibility, family supportive workplace, or work-family conflict).

H6: A father's warmth will vary as a function of the interaction between his fathering attitudes and his work characteristics.

\section{Data and Methods}

\section{Data}

This study used the Survey of Contemporary Fatherhood (SCF), a Brigham Young University Institutional Review Board approved survey investigating factors predictive of positive father involvement (see Petts et al., 2018). SCF is a national sample of 2,297 fathers, social fathers, stepfathers, and father figures in the United States, collected in 2015. To be included in SCF, respondents had to be (a) at least 18 years old; (b) a biological (residential or nonresidential) father, residential stepfather, or residential father figure (defined as living with a nonbiological, nonadopted child in a home with the child's biological or adoptive mother, but not in a marital relationship); (c) have English language proficiency, and (d) the ability to access the survey via the Internet. Fathers responded to questions about the father's youngest child between the ages of 2 and 18 .

$\mathrm{SCF}$ is a quota sample, as these can capture various father roles (biological parent, stepparent, etc.) and produce results similar to random samples (Weinberg, Freese, \& McElhattan, 2014). Respondents were part of a Qualtrics opt-in online panel. Qualtrics panelists are recruited through online and off-line advertising and must register to be eligible. Panelists are restricted in the number of surveys they may complete annually, must maintain their information to remain in the panel, and are monitored on sociodemographic questions to ensure consistency across responses. Qualtrics provides access to approximately 100,000 panelists, who are randomly selected and proportioned for surveys according to the general population. Once individuals were randomly selected, they were contacted about potential eligibility for the survey and provided a link to a screening site where final eligibility was determined.

Several data quality checks (e.g., attention filters and survey minimums) were used per guidelines from the American Association for Public Opinion Research (Baker et al., 2010). Multiple demographic characteristics were also used in the sampling scheme and screening process to reduce bias (Smith, Roster, Golden, \& Albaum, 2016; Terhanian, Bremer, Olmsted, \& Guo, 2016). Postcollection data quality checks were performed, which removed approximately $4 \%$ of respondents from the sample.

Online opt-in panels are representative of individuals with regular access to the Internet (Tourangeau, Conrad, \& Couper, 2013), yet, they may underrepresent marginalized groups. Although it is unclear what the overall Qualtrics panel looks like, more than $80 \%$ of adult Americans have regular access to the Internet, and racial gaps in Internet usage have closed considerably since 2012, although gaps due to income, education, and rural versus urban communities persist (Pew Research Center, 2016). Consistent with other studies using quota sampling, results from this study are not nationally representative; nonresident fathers, low SES fathers, and racial/ethnic minorities may be underrepresented (Yang \& Banamah, 2014), consequently we cannot explore differences in processes specific to these groups. The quality of measures used and large national sample still provide useful insight into associations between a father's workplace, his attitudes, and his involvement.

SCF was designed with developmentally appropriate measures of father involvement; different questions were asked about chil- 
dren aged 2 to 8 and children aged 9 to 18 . For this study, we focused on involvement with younger children $(N=1,194)$. We further restricted the sample to focus only on employed fathers $(N=1,038)$ and excluded fathers who reported on a foster child or other child (i.e., grandchild or niece/nephew). The final sample was 1,020 fathers.

\section{Father Involvement}

Two indicators of father involvement are used. Both indicators are measured with items taken from the Early Childhood Longitudinal Survey-Birth Cohort (ECLS-B). Engagement indicates how often $(1=$ never to $6=$ more than once a day $)$ fathers engage in 15 activities with their child such as playing, telling stories, and taking on errands $(\alpha=.90)$. The mean is used as the indicator. Warmth is indicated by eight items such as praising child, hugging and kissing child, and using affectionate nicknames. Items are assessed on a 1 (not at all like me) to 5 (exactly like me) scale. The mean is used as the indicator $(\alpha=.87)$.

\section{Father Attitudes}

We assess fathers' adherence to the new fatherhood ideal through responses to a series of statements ( $1=$ strongly disagree to 5 = strongly agree; McGill, 2014): (a) "it is essential for the child's well-being that fathers spend time interacting and playing with their children," (b) "it is difficult for men to express warm and tender affectionate feelings toward children (reverse coded)," (c) "a father should be as heavily involved in the care of his child as the mother," (d) "fathers play a central role in the child's personality development," (e) "fathers are able to enjoy children more when they are older (reverse coded)," (f) "the way a parent treats a child in the first 4 years has important lifelong effects," (g) "if it keeps him from getting ahead in his job, a father is too involved with his children (reverse coded)", and (h) "in general, fathers and mothers are equally good at meeting their children's needs." The mean is used as the indicator $(\alpha=.70)$.

We assess fathers' adherence to gender role norms through items from the National Survey of Families and Households (https:// www.ssc.wisc.edu/nsfh/; ranging from $1=$ strongly disagree to 4 = strongly agree): (a) "if a husband and wife both work full-time, they should share household tasks equally," (b) "women are much happier if they stay at home and take care of their children," (c) "it is much better for everyone if the man earns the living and the woman takes care of the home and family," (d) "it is more important for a wife to help her husband's career than have one of her own," (e) "an employed mother can establish a warm and secure relationship with her children as much as a mother who is not employed," (f) "parents should encourage just as much independence in their daughters as their sons," (g) "preschool children are likely to suffer if their mother is employed," (h) "being a father and raising children is one of the most fulfilling experiences a man can have," and (i) "mothers should not work full time if their child is younger than 5 years old." Higher values indicate more traditional gender norms, and the mean is used as the indicator $(\alpha=.80)$.

\section{Workplace Characteristics}

Three indicators are used to assess whether fathers' work environments reflect resources or demands per our theoretical framework; each has been used in prior studies (Bond, Thompson, Galinsky, \& Prottas, 2003; Dolcos \& Daley, 2009). Family workplace support indicates how often fathers feel they receive support from their employers and coworkers $(0=$ never to $4=$ very often $)$. Items include (a) "my supervisor accommodates me when I have family or personal business to take care of," (b) "my supervisor is understanding when I talk about personal or family issues that affect my work," (c) "I feel comfortable bringing up personal or family issues with my supervisor," (d) "my supervisor really cares about the effects that work demands have on my personal and family life," and (e) "I have support from coworkers that helps me to manage my work and personal or family life" $(\alpha=.89)$. Job flexibility indicates the level of flexibility fathers believe they have at their job $(0=$ no flexibility to $4=$ complete flexibility $)$ over (a) where they work and (b) when they work $(\alpha=.86)$. Work-family conflict is taken from five items that assess how often during the past three months $(0=$ never to $4=$ very often $)$ fathers have: (a) "not had enough time for themselves because of their job," (b) "not had enough time for their family or other important people in their life because of their job," (c) "not had the energy to do things with their family or other important people in their life because of their job," (d) "not been able to get everything done at home each day because of their job," and (e) "not been in as good a mood as they would like to be at home because of their job." The mean is used as the indicator $(\alpha=.91)$.

\section{Control Variables}

A variety of controls were also used. These include father's age, race/ethnicity (White, Black, Latino, and other race/ethnicity, with White serving as the reference category), education ( $1=$ did not complete high school to $5=$ completed a graduate degree), income $(1=$ no income to $8=\$ 140,000$ or more $)$, hours worked, and whether the father reported having a professional, managerial, or executive occupation $(1=y e s)$. Family structure is indicated by a set of mutually exclusive variables that assess fathers' resident status and relationship to the birth mother. These include (a) father is married to the birth mother (reference category), (b) father cohabits with birth mother, (c) father resides with child and is married to, or cohabiting with, someone other than the birth mother, (d) single father, and (e) nonresident father. Additional controls are also included to indicate whether the father is a stepfather (biological/adoptive father is the reference category), how many other children the father has, focal child's age, sex of focal child $(1=$ male $)$, and whether the father was born in the United States. Father's religiosity is indicated by responses to 11 items from the Centrality of Religiosity Scale, which assesses involvement in religious behaviors and experiences (Huber \& Huber, 2012). Six items from the Nurturant Fathering Scale (Finley \& Schwartz, 2004) are used to indicate fathers' perceptions of their relationship with their own father $(\alpha=.95)$, and the mean is used as the indicator. Finally, fathers were asked about their involvement $(1=y e s)$ in a number of activities during their child's prenatal and early postnatal periods. These include (a) attending an ultrasound, (b) attending doctor's visits with mother, (c) hearing child's heartbeat, (d) feeling child move, (e) attending a childbirth 
class, (f) buying things for child prior to birth, (g) asking mother how pregnancy was going, (h) being present in delivery room, (i) visiting child in the hospital, and (j) attending a well-baby visit in the first year of child's life. Responses are summed to create an index of prenatal involvement.

\section{Analysis Plan}

Ordinary least squares (OLS) regression models were used to assess whether father attitudes and workplace characteristics are associated with each indicator of father involvement. To test hypotheses about interactions between father attitudes and workplace characteristics, we ran a series of two-way ineractions (i.e., six total interaction terms; 2 Indicators of Father Attitudes $\times 3$ Indicators of Workplace Characteristics) using a hierarchical modeling approach. Thus, we added each individual interaction term to test for significance $(p<.05)$ to our model including all controls and main effects. Simple slopes analysis and region of significance analysis were conducted to better understand the interaction effects, and meaningful results from these analyses are presented graphically and in the text. We concluded with a full interactive model for each type of father involvement. Less than $5 \%$ of respondents have missing values, but multiple imputation was used in all models (combined results from 10 imputed models are presented).

\section{Results}

Summary statistics for all variables are presented in Table 1 to describe the sample of fathers used in this study. Results suggest that fathers in the SCF are engaged with their children at least a few times a week $(M=4.26)$ and state that warm behaviors are "very much like me" $(M=4.17)$. Yet, fathers in the SCF report limited family support by their workplace; on average, fathers report feeling supported at work between sometimes and often $(M=2.45)$, sometimes experiencing work-family conflict $(M=$ $1.80)$, and having little to some flexibility at their jobs $(M=1.53)$. In addition, fathers in the SCF appear to be more supportive of egalitarian than traditional gender role norms; on average, fathers agree with statements associated with the new fatherhood ideal $(M=4.02)$ and disagree with statements associated with traditional gender norms $(M=1.93)$. Zero-order correlations between variables of interest are presented in Table 2.

\section{Father Attitudes and Father Involvement}

Results from regression models testing the first two hypotheses are presented in Table 3. We find mixed evidence in support of our first hypothesis; endorsing traditional gender role norms is unrelated to engagement, but adherence to the new fatherhood ideal is positively associated with engagement $(b=0.14, p<.001)$. We find consistent support for our second hypothesis; endorsing traditional gender role norms is negatively associated with warmth ( $b=-0.11, p<.01)$, while adherence to the new fatherhood ideal is positively associated with father warmth $(b=0.56, p<.001)$. In each respective model, standarized coefficients suggest that attitudes about new fatherhood are among the strongest predictors of father engagement $(B=0.14, p<.001)$, and warmth $(B=0.47$, $p<.001)$.
Table 1

Summary Statistics

\begin{tabular}{|c|c|c|c|c|}
\hline Variable & $M$ or $\%$ & $S D$ & Min & Max \\
\hline \multicolumn{5}{|l|}{ Father involvement } \\
\hline Engagement & 4.25 & 0.80 & 1 & 6 \\
\hline Warmth & 4.17 & 0.64 & 1 & 5 \\
\hline \multicolumn{5}{|l|}{ Father attitudes } \\
\hline New fatherhood ideal & 4.02 & 0.54 & 1 & 5 \\
\hline Gender role norms & 1.93 & 0.48 & 1 & 4 \\
\hline \multicolumn{5}{|l|}{ Workplace characteristics } \\
\hline Family workplace support & 2.45 & 0.98 & 0 & 4 \\
\hline Work-family conflict & 1.80 & 0.96 & 0 & 4 \\
\hline Job flexibility & 1.53 & 1.11 & 0 & 4 \\
\hline \multicolumn{5}{|l|}{ Controls } \\
\hline Age & 35.12 & 7.91 & 19 & 67 \\
\hline White $^{\mathrm{a}}$ & $70 \%$ & - & 0 & 1 \\
\hline Black & $9 \%$ & - & 0 & 1 \\
\hline Latino & $14 \%$ & - & 0 & 1 \\
\hline Other race & $7 \%$ & - & 0 & 1 \\
\hline U.S. native & $94 \%$ & - & 0 & 1 \\
\hline Education & 3.41 & 0.99 & 1 & 5 \\
\hline Income & 4.68 & 1.61 & 1 & 8 \\
\hline Hours worked & 40.95 & 7.67 & 4 & 50 \\
\hline Professional occupation & $53 \%$ & - & 0 & 1 \\
\hline Spouse/partner employed & $53 \%$ & - & 0 & 1 \\
\hline Married to birth mother ${ }^{\mathrm{a}}$ & $68 \%$ & - & 0 & 1 \\
\hline Cohabiting with birth mother & $16 \%$ & - & 0 & 1 \\
\hline Residing with other partner & $2 \%$ & - & 0 & 1 \\
\hline Single father & $8 \%$ & - & 0 & 1 \\
\hline Nonresident father & $5 \%$ & - & 0 & 1 \\
\hline Stepfather & $7 \%$ & - & 0 & 1 \\
\hline Number of other children & 1.17 & 1.11 & 0 & 4 \\
\hline Own father involvement & 3.45 & 1.13 & 1 & 5 \\
\hline Prenatal involvement & 8.01 & 2.87 & 0 & 10 \\
\hline Religiosity & 3.23 & 1.06 & 1 & 5 \\
\hline Focal child age & 4.62 & 2.00 & 2 & 8 \\
\hline Focal child is male & $59 \%$ & - & 0 & 1 \\
\hline
\end{tabular}

Note. $\quad N=1,020$.

${ }^{\text {a }}$ Used as reference category.

\section{Workplace Characteristics and Father Involvement}

Table 3 also provides the results for the tests of our third and fourth hypotheses. Consistent with our third hypothesis, having a family supportive workplace $(b=0.10, p<.001)$, and having job flexibility $(b=0.07, p<.01)$ are each associated with more frequent father engagement. Work-family conflict was not, however, related to father engagement. We received less support for our fourth hypothesis. Although having a family supportive workplace is associated with being more likely to display warmth toward children $(b=0.06, p<.01)$, job flexibility and workfamily conflict were unrelated to warmth.

\section{Father Attitudes, Workplace Characteristics, and Father Involvement}

Results from regression models testing our fifth and sixth hypotheses are presented in Table 4. First, there is some evidence that workplace characteristics may moderate the relationship between father attitudes and father engagement. Specifically, one interaction term was significant when all other variables were in the model (Engagement Model 1); the association between fathers' endorsement of the new fatherhood ideal and engagement varies 
Table 2

Correlation Matrix

\begin{tabular}{|c|c|c|c|c|c|c|c|}
\hline Variable & 1 & 2 & 3 & 4 & 5 & 6 & 7 \\
\hline 1. Engagement & - & & & & & & \\
\hline 2. Warmth & $0.37^{*}$ & - & & & & & \\
\hline 3. New fatherhood ideal & $0.18^{*}$ & $-0.57^{*}$ & - & & & & \\
\hline 4. Gender role norms & -0.03 & $-0.30^{*}$ & $-0.45^{*}$ & - & & & \\
\hline 5. Family workplace support & $0.20^{*}$ & $-0.24^{*}$ & $0.24^{*}$ & $-0.14^{*}$ & - & & \\
\hline 6. Work-family conflict & $-0.06^{*}$ & $-0.13^{*}$ & $-0.18^{*}$ & $0.15^{*}$ & $-0.21^{*}$ & - & \\
\hline 7. Job flexibility & $0.17^{*}$ & 0.05 & -0.05 & 0.02 & $0.17^{*}$ & $-0.23^{*}$ & - \\
\hline
\end{tabular}

* Indicates significant correlation at $p<.05$.

by fathers' job flexibility $(b=-0.15, p<.001$ ). As shown in Figure 2, fathers who endorse the new fatherhood ideal are highly engaged with their children regardless of how flexible their jobs are. In contrast, job flexibility appears to be an important predictor of engagement for fathers with lower endorsements of the new fatherhood ideal (i.e., neutral or slightly disagree with these statements). Among fathers who indicate slight disagreement with the new fatherhood ideal, those with high job flexibility engage with their children approximately daily (predicted value of 4.67) whereas those with no job flexibility engage with their children between a few times a month and a few times a week (predicted value of 3.45) — a difference of $1.5 S D \mathrm{~s}(p<.001)$. In addition, among fathers who are neutral about the new fatherhood ideal, those with complete job flexibility are engaged with their child approximately $1 S D$ more frequently compared to fathers with no flexibility $(p<.001)$. Simple slopes analyses confirm that job flexibility is more likely to promote father engagement among traditional fathers than those who embrace the new fatherhood ideal (see Figure S1 in the online supplemental material).

Results in Warmth Models 2-5 of Table 4 provide evidence for the sixth hypothesis that workplace characteristics may moderate the relationship between father attitudes and father warmth. The association between endorsement of the new fatherhood ideal and warmth varies by job flexibility $(b=-0.07, p<.05$; see Warmth Model 2). Additional analyses suggest the moderating relationship only holds true when comparing very divergent levels of job

Table 3

Results From Ordinary Least Squares Regression Models Predicting Father Involvement

\begin{tabular}{|c|c|c|c|c|c|c|}
\hline \multirow[b]{2}{*}{ Variable } & \multicolumn{3}{|c|}{ Engagement } & \multicolumn{3}{|c|}{ Warmth } \\
\hline & $b$ & $S E b$ & $B$ & $b$ & $S E b$ & $B$ \\
\hline New fatherhood ideal & $0.21^{* * * *}$ & 0.05 & $0.14^{* * * *}$ & $0.56^{* * * *}$ & 0.08 & $0.47^{* * * *}$ \\
\hline Gender role norms & 0.04 & 0.06 & 0.03 & $-0.11^{* *}$ & 0.04 & $-0.08^{* *}$ \\
\hline Family workplace support & $0.10^{* * * *}$ & 0.02 & $0.11^{* * * *}$ & $0.06^{* * *}$ & 0.13 & $0.09^{* *}$ \\
\hline Work-family conflict & 0.01 & 0.02 & 0.01 & 0.02 & 0.02 & 0.03 \\
\hline Job flexibility & $0.07^{* * *}$ & 0.02 & $0.09^{* * *}$ & 0.02 & 0.02 & 0.03 \\
\hline \multicolumn{7}{|l|}{ Controls } \\
\hline Age & $-0.02^{* * * *}$ & 0.00 & $-0.15^{* * *}$ & -0.00 & 0.00 & -0.03 \\
\hline Black & -0.03 & 0.08 & -0.01 & -0.06 & 0.06 & -0.03 \\
\hline Latino & 0.03 & 0.07 & 0.01 & 0.03 & 0.05 & 0.01 \\
\hline Other race & 0.03 & 0.09 & 0.01 & -0.04 & 0.06 & -0.02 \\
\hline U.S. native & 0.06 & 0.10 & 0.02 & $-0.15^{*}$ & 0.07 & $-0.05^{*}$ \\
\hline Education & $-0.09^{* *}$ & 0.03 & $-0.11^{* *}$ & -0.02 & 0.02 & -0.03 \\
\hline Income & $0.04^{*}$ & 0.02 & $0.08^{*}$ & 0.02 & 0.01 & 0.05 \\
\hline Hours worked & -0.00 & 0.00 & -0.04 & $-0.01^{*}$ & 0.00 & $-0.07^{*}$ \\
\hline Professional occupation & -0.07 & 0.05 & -0.04 & -0.06 & 0.04 & -0.05 \\
\hline Spouse/partner employed & $0.17^{* *}$ & 0.05 & $0.11^{* *}$ & -0.02 & 0.04 & -0.02 \\
\hline Cohabiting & 0.05 & 0.07 & 0.02 & -0.03 & 0.05 & -0.01 \\
\hline Other partner & -0.20 & 0.15 & -0.04 & 0.05 & 0.11 & 0.01 \\
\hline Single father & 0.16 & 0.09 & 0.06 & 0.02 & 0.06 & 0.01 \\
\hline Nonresident father & $-0.30^{* *}$ & 0.11 & $-0.08^{* *}$ & -0.02 & 0.08 & -0.00 \\
\hline Stepfather & $0.25^{*}$ & 0.11 & $0.08^{*}$ & 0.15 & 0.08 & 0.06 \\
\hline Number of other children & $-0.05^{*}$ & 0.02 & $-0.06^{*}$ & 0.01 & 0.02 & 0.01 \\
\hline Own father involvement & $0.09^{* * * *}$ & 0.02 & $0.13^{\text {***** }}$ & 0.00 & 0.02 & 0.01 \\
\hline Prenatal involvement & $0.05^{* * * *}$ & 0.01 & $0.17^{* * * *}$ & $0.04^{* * * *}$ & 0.01 & $0.16^{* * *}$ \\
\hline Religiosity & $0.16^{* * * *}$ & 0.02 & $0.21^{* * * * *}$ & $0.06^{* * * *}$ & 0.02 & $0.10^{* * * *}$ \\
\hline Focal child age & $-0.05^{* * * *}$ & 0.01 & $-0.12^{* * * *}$ & $-0.04^{* * * *}$ & 0.01 & $-0.13^{* * * *}$ \\
\hline Focal child is male & -0.02 & 0.05 & -0.02 & $-0.10^{\text {*** }}$ & 0.03 & $-0.07^{\text {*** }}$ \\
\hline$R^{2}$ & & 0.27 & & & 0.40 & \\
\hline
\end{tabular}

Note. $\quad N=1020$.

${ }^{*} p<.05{ }^{* * *} p<.01 .{ }^{* * *} p<.001$. 
flexibility. As shown in Figure S2 in the online supplemental material, fathers who highly endorse the new fatherhood ideal act warmly toward their children regardless of how flexible their jobs are. In contrast, job flexibility appears to be important for fathers who are less likely to adhere to the new fatherhood ideal (i.e., neutral or slightly disagree with these statements); among fathers in this sample who have the lowest adherence to the new fatherhood ideal, those who have flexible jobs act warmly toward their children approximately $3 / 4 S D$ more frequently than those who have less flexible jobs. Simple slopes analyses (Figure S3 in the online supplemental material) confirm that job flexibility is more likely to promote warmth among fathers who do not endorse the new fatherhood ideal than those who do.

Similarly, as shown in Warmth Model 3 of Table 4, associations between a family supportive workplace and warmth vary by the degree to which fathers endorse the new fatherhood ideal $(b=$ $-0.12, p<.001)$. As shown in Figure 3, fathers who highly endorse the new fatherhood ideal act warmly toward their children regardless of whether they have a family supportive workplace. In contrast, workplace support is an important predictor of warmth for fathers who are less likely to adhere to the new fatherhood ideal. Among fathers with the lowest support for the new fatherhood ideal, those who receive family workplace support very often act warmly toward their children $1.5 S D$ more frequently than fathers who never receive such support $(p<.001)$. In addition, among fathers who are neutral toward the new fatherhood ideal, those who receive workplace support very often act warmly toward their children over $1 S D$ more frequently compared to those who never receive workplace support. Simple slopes analyses confirm that workplace support is more likely to promote warmth among fathers who are less likely to endorse the new fatherhood ideal (see Figure S4 in the online supplemental material).

In addition, as shown in Warmth Model 4 of Table 4, the association between workplace support and warmth varies by the degree to which fathers endorse traditional gender role norms ( $b=$ 0.08, $p<.05)$. This is depicted in Figure S5 in the online supplemental material, which shows that fathers who are less traditional act warmly toward their children regardless of whether they have a supportive workplace. In contrast, workplace support appears to be an important predictor of warmth for more traditional fathers; among fathers who highly endorse traditional gender roles, those who have highly supportive workplaces act warmly toward their children $1.5 S D$ more frequently than those who never receive support from their workplace. Simple slopes analyses confirm that workplace support is more likely to promote warmth among traditional fathers than egalitarian fathers (see results in Figure S6 in the online supplemental material).

When all interaction terms predicting warmth are included in the same model (Warmth Model 5 of Table 4), only one remains significant: the association between adherence to new fatherhood ideals and warmth varies by family workplace support $(b=$ $-0.10, p<.05)$. The graph and simple slopes analyses demonstrate that among fathers who are less likely to endorse the new fatherhood ideal, the degree to which they act warmly toward their children is dependent on the degree to which they receive workplace support (see Figure 3 and Figure S4 in the online supplemental material). 


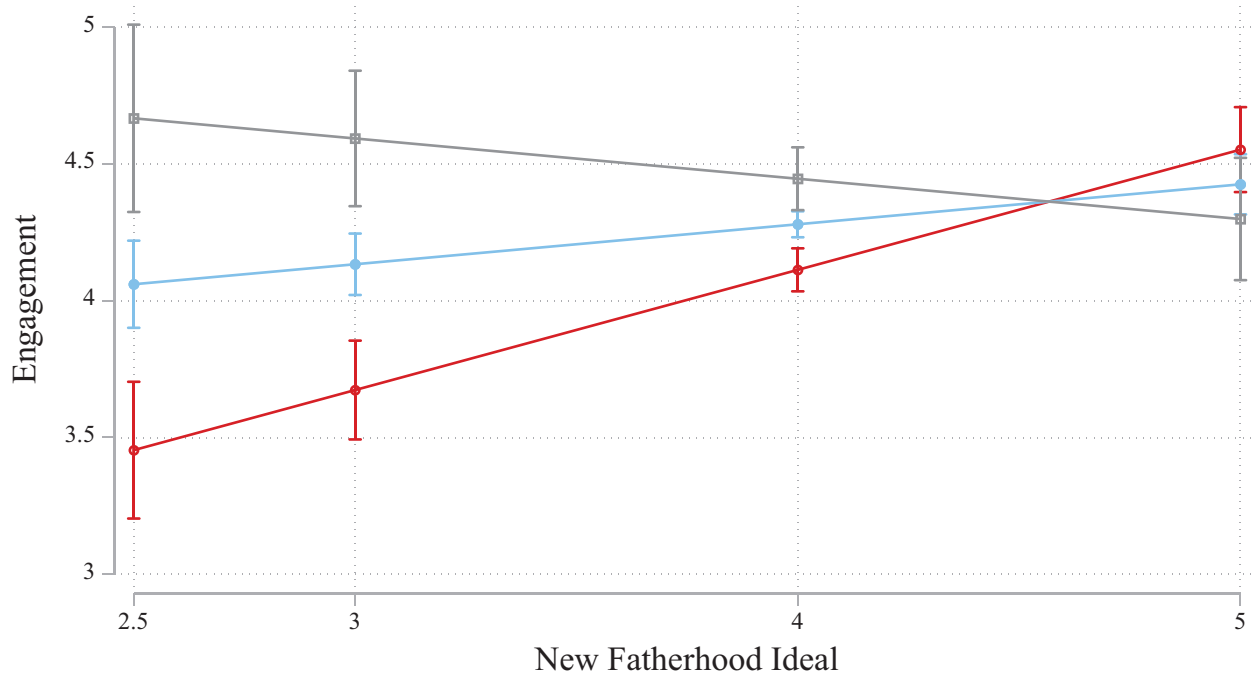

$\rightarrow$ No flexibility $\rightarrow$ Some flexibility $\rightarrow$ Complete flexibility

Figure 2. Moderating influence of job flexibility on the relationship between adherence to the new fatherhood ideal and engagement. See the online article for the color version of this figure.

\section{Discussion}

Despite the fact that many fathers want to be warmer, more nurturing, and more actively involved parents than prior generations (McGill, 2014), they also still embrace a father's role as financial earner for his family (Kuo et al., 2018). Thus, fathers may feel torn between the potentially competing demands of being a breadwinner and being a warm and actively engaged father (Kuo et al., 2018).Variations in father involvement are rooted in a systemic ecological approach to fathering (Cabrera et al., 2014; Holmes et al., 2010; Holmes \& Huston, 2010), emphasizing that a father's attitudes likely interact with his contextual environments to predict father involvement. In this paper, we explored the associations between fathers' attitudes (e.g., traditional gender role norms and endorsement of the new fatherhood ideal), workplace characteristics (e.g., job flexibility, a family supportive workplace, and work-family conflict) and father involvement (e.g., engagement and warmth). Results largely support our theoretical model predicting that fathers' attitudes and work characteristics are associated with father involvement both independently and interactively.

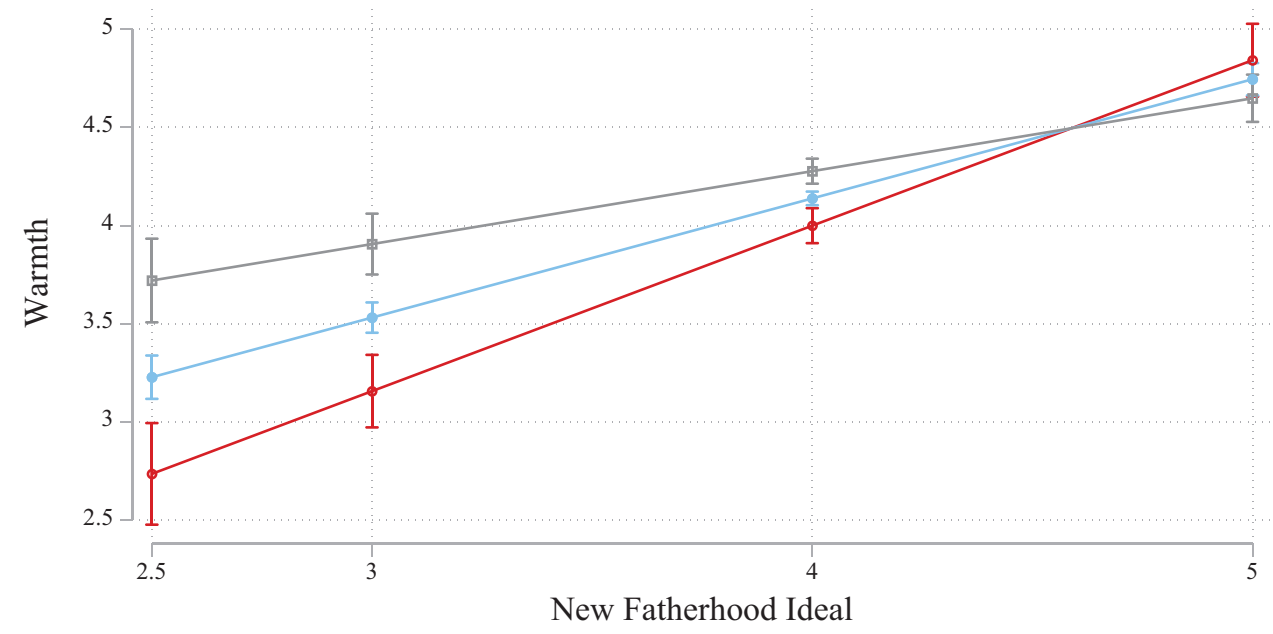

$\rightarrow$ Never receives support
$\rightarrow-$ Very often receives support

Figure 3. Moderating influence of family workplace support on the relationship between adherence to the new fatherhood ideal and warmth. See the online article for the color version of this figure. 
As expected, fathering attitudes were significantly associated with engagement and warmth. Our results demonstrate that fathers who adhere to the new fatherhood ideal (i.e., the idea that contemporary fathers can be more nurturing than fathers in prior generations were, and can make meaningful contributions to child development) are more engaged and warmer with their children than fathers who do not endorse the ideal. While endorsing traditional gender role norms was not associated with engagement, endorsing traditional gender role norms was associated with lower warmth in our sample. Consistent with prior research (Holmes \& Huston, 2010; Petts et al., 2018), fathering attitudes are associated with fathering behaviors, even after controlling for prenatal involvement and a host of other key demographic variables. Because quality father involvement (including being engaged and genuinely warm) helps children and fathers (Dyer et al., 2014; Eggebeen et al., 2012; Flouri et al., 2016; Palkovitz et al., 2001; Pleck, 2010), knowing which father attitudes impact multiple dimensions of father involvement can be useful for both prevention and intervention efforts with fathers.

Consistent with our hypotheses, having a family supportive workplace and job flexibility were each associated with more frequent father engagement. Having a family supportive workplace was also associated with greater father warmth. These findings expand on prior work linking job flexibility and a family supportive workplace to the work-family interface (e.g., Voydanoff, 2004; Hill et al., 2010; Mesmer-Magnus \& Viswesvaran, 2006) by demonstrating that father engagement and warmth are also enhanced by these resources.

Most importantly, we found support for our theoretical claim that the effects of father attitudes and work characteristics interactively contribute to a father's engagement and warmth with his young children. After controlling for all other possible controls, main effects and other interactions, we found a significant interaction between the new fatherhood ideal and job flexibility on father engagement. This significant interaction demonstrated that access to job flexibility matters more for father engagement among fathers who do not endorse the new nurturing fatherhood ideal than fathers who do. More specifically, we found that fathers with high job flexibility who indicate disagreement with the new fatherhood ideal were engaged with their young children almost daily. Fathers with similar attitudes and no job flexibility engaged with their children between a few times a month and a few times a week. This nuance demonstrates that job flexibility may be particularly meaningful for father engagement among fathers who would otherwise be less committed to engagement with their young children

Similarly, among fathers who do not adhere to the new fatherhood ideal, those who have a high degree of family support from their workplace act warmer toward their child than those who receive less workplace support. Additional analyses revealed that fathers with the lowest endorsement of the new fatherhood ideal and fathers who are neutral toward the new fatherhood ideal who receive high levels of family workplace support act warmly toward their children significantly more frequently than fathers who never receive such support.

These findings suggest that employers, supervisors, and coworkers have a unique opportunity to shape men's engagement with their young children by creating an environment that enables even those more traditionally oriented fathers to be involved in their young children's lives. Research of the past four decades is clear in showing that engaged fathering has the potential to foster child and adolescent social, emotional (Day \& Padilla-Walker, 2009), and overall wellbeing (Flouri et al., 2016), as well as men's healthy development (Eggebeen et al., 2012). Employers may also benefit as involved fathers report improved job performance, greater job enhancements, and fewer strains (Graves et al., 2007).

\section{Limitations}

Despite its strengths, our study includes some important limitations that point us toward directions for future research. First, a general weakness in the work-family literature is a lack of longitudinal data (Hill \& Holmes, 2018). This project is no different. While we try to account for some features of a father's earlier involvement by controlling for prenatal involvement, there is still a lingering question about whether or not workplace characteristics lead to changes in father involvement. It could be that more involved fathers seek workplaces that are more flexible and better assist fathers in balancing work and family life. Although we are not able to fully assess this given the use of cross-sectional data, additional models (available upon request) suggest that fathers' attitudes and warmth are unrelated to job flexibility, but father engagement is positively associated with job flexibility. Future research should explore potential bidirectionality.

Second, this project uses father self-report data to establish connections between father involvement and the workplace. Fathers may overreport their involvement; indeed, fathers in this sample report moderate to high levels of warmth and engagement. We ran additional models to assess the robustness of our findings; results from logistic regression models predicting high levels of involvement were largely consistent with results reported here. The reports of mothers, children, or outside observers could minimize concern about shared method bias.

\section{Conclusion}

Prior research has established that flexibility and family support are great for employees, reducing demands between work and family (Hill et al., 2010; Mesmer-Magnus \& Viswesvaran, 2006). We build on these findings by demonstrating that flexibility and workplace support help fathers who do not endorse the new fatherhood ideal to stay connected with their young children. Future research should explore how these benefits to enhancing men's engagement and warmth with their children help employers retain key talent in their business, improve employee performance, and enhance employee job satisfaction. It could be that when employers give fathers resources to balance work and family life, fathers will give employers more in return.

\section{References}

Allen, T. D. (2001). Family-supportive work environments: The role of organizational perceptions. Journal of Vocational Behavior, 58, 414435. http://dx.doi.org/10.1006/jvbe.2000.1774

Allen, T. D., Johnson, R. C., Kiburz, K. M., \& Shockley, K. M. (2013). Work-family conflict and flexible work arrangements: Deconstructing flexibility. Personnel Psychology, 66, 345-376.

Aumann, K., Galinsky, E., \& Matos, K. (2011). The new male mystique. New York, NY: Families and Work Institute. 
Baker, R., Blumberg, S. J., Brick, J. M., Couper, M. P., Courtright, M., Dennis, J. M., . . Zahs, D. (2010). AAPOR report on online panels. Public Opinion Quarterly, 74, 711-781. http://dx.doi.org/10.1093/poq/ nfq048

Behson, S., Holmes, E. K., Hill, E. J., \& Robbins, N. (2018). Fatherhood, work, and family across the globe: A review and research agenda. In $\mathrm{K}$. Shockley, W. Shen, \& R. Johnson (Eds.), The Cambridge handbook of the global work-family interface (Cambridge Handbooks in Psychology; pp. 614-628). Cambridge, UK: Cambridge University Press. http://dx doi.org/10.1017/9781108235556.033

Bond, J. T., Thompson, C. A., Galinsky, E., \& Prottas, D. (2003). Highlights of the 2002 National Study of the Changing Workforce. New York, NY: Families and Work Institute.

Brotherson, S. E., Yamamoto, T., \& Acock, A. (2003). Connection and communication in fatherchild relationships and adolescent child wellbeing. Fathering: A Journal of Theory, Research, and Practice about Men as Fathers, 1, 191-214.

Brown, G. L., Mangelsdorf, S. C., \& Neff, C. (2012). Father involvement, paternal sensitivity, and father-child attachment security in the first 3 years. Journal of Family Psychology, 26, 421-430. http://dx.doi.org/10 $.1037 / \mathrm{a} 0027836$

Burnett, S. B., Gatrell, C. J., Cooper, C., \& Sparrow, P. (2013). Fathers at work: A ghost in the organizational machine. Gender, Work and Organization, 20, 632-646.

Cabrera, N., Fitzgerald, H., Bradley, R. H., \& Roggman, L. A. (2014). The ecology of father-child relationships: An expanded model. Journal of Family Theory \& Review, 6, 336-354.

Cooklin, A. R., Westrupp, E. M., Strazdins, L., Giallo, R., Martin, A., \& Nicholson, J. M. (2016). Fathers at work: Work-family conflict, workfamily enrichment and parenting in an Australian cohort. Journal of Family Issues, 37, 1611-1635. http://dx.doi.org/10.1177/0192513X 14553054

Davidov, M., \& Grusec, J. E. (2006). Untangling the links of parental responsiveness to distress and warmth to child outcomes. Child Development, 77, 44-58. http://dx.doi.org/10.1111/j.1467-8624.2006.00855.x

Day, R. D., \& Padilla-Walker, L. M. (2009). Mother and father connectedness and involvement during early adolescence. Journal of Family Psychology, 23, 900-904. http://dx.doi.org/10.1037/a0016438

Dolcos, S. M., \& Daley, D. (2009). Work pressure, workplace social resources, and work-family conflict: The tale of two sectors. International Journal of Stress Management, 16, 291-311. http://dx.doi.org/10 $.1037 / \mathrm{a} 0017319$

Dyer, W. J., Day, R. D., \& Harper, J. M. (2014). Father involvement: Identifying and predicting family members' shared and unique perceptions. Journal of Family Psychology, 28, 516-528. http://dx.doi.org/10 $.1037 / \mathrm{a} 0036903$

Eggebeen, D. J., Knoester, C., \& McDaniel, B. T. (2012). The implications of fatherhood for men. In N. Cabrera \& C. S. Tamis-LeMonda (Eds.), Handbook of father involvement: Multidisciplinary perspectives (2nd ed., pp. 338-357). Mahwah, NJ: Erlbaum.

Flouri, E., Midouhas, E., \& Narayanan, M. K. (2016). The relationship between father involvement and child problem behavior in intact families: A 7-year cross-lagged study. Journal of Abnormal Child Psychology, 44, 1011-1021. http://dx.doi.org/10.1007/s10802-015-0077-9

Finley, G. E., \& Schwartz, S. J. (2004). The father involvement and nurturant fathering scales: Retrospective measures for adolescent and adult children. Educational and Psychological Measurement, 64, 143164. http://dx.doi.org/10.1177/0013164403258453

Graves, L. M., Ohlott, P. J., \& Ruderman, M. N. (2007). Commitment to family roles: Effects on managers' attitudes and performance. Journal of Applied Psychology, 92, 44-56. http://dx.doi.org/10.1037/0021-9010.92 .1 .44

Hill, E. J., Erickson, J. J., Holmes, E. K., \& Ferris, M. (2010). Workplace flexibility, work hours, and work-life conflict: Finding an extra day or two. Journal of Family Psychology, 24, 349-358. http://dx.doi.org/10 .1037/a0019282

Hill, E. J., \& Holmes, E. K. (2018). Families and workplaces. In. B. H. Fiese, M. Celano, K. Deater-Deckard, E. N. Jouriles, \& M. A. Whisman (Eds.), APA handbook of contemporary family psychology: Vol. 2. Applications and broad impact of family psychology (pp. 379-395). Washington, DC: American Psychological Association.

Holmes, E. K., Baumgartner, J., Marks, L. D., Palkovitz, R., \& Nesteruk, O. (2010). Contemporary contradictions and challenges facing married fathers and mothers. In K. S. Pearlman (Ed.), Marriage: Roles, stability, and conflict (pp. 157-171). Hauppage, NY: Nova Science.

Holmes, E. K., \& Huston, A. C. (2010). Understanding positive fatherchild interaction: Children's, fathers', and mothers' contributions. Fathering: A Journal of Theory, Research, and Practice about Men as Fathers, 8, 203-225. http://dx.doi.org/10.3149/fth.1802.203

Huber, S., \& Huber, O. W. (2012). The centrality of religiosity scale (CRS). Religions, 3, 710-724. http://dx.doi.org/10.3390/rel3030710

Kossek, E. E., Pichler, S., Bodner, T., \& Hammer, L. B. (2011). Workplace social support and work-family conflict: A meta-analysis clarifying the influence of general and work-family-specific supervisor and organizational support. Personnel Psychology, 64, 289-313. http://dx.doi.org/10 $.1111 / \mathrm{j} .1744-6570.2011 .01211 . \mathrm{x}$

Kuo, P. X., Volling, B. L., \& Gonzalez, R. (2018). Gender role beliefs, work-family conflict, and father involvement after the birth of a second child. Psychology of Men \& Masculinity, 19, 243-256. http://dx.doi.org/ 10.1037/men0000101

Marsiglio, W., \& Roy, K. (2012). Nurturing dads: Social initiatives for contemporary fatherhood. New York, NY: Russell Sage Foundation.

McGill, B. S. (2014). Navigating new norms of involved fatherhood: Employment, fathering attitudes, and father involvement. Journal of Family Issues, 35, 1089-1106. http://dx.doi.org/10.1177/0192513X 14522247

McKelley, R. A., \& Rochlen, A. B. (2016). Furthering fathering: What we know and what we need to know. In Y. J. Wong, \& S. R. Wester (Ed.), APA handbook of men and masculinities (pp. 525-549). Washington, DC: American Psychological Association. http://dx.doi.org/10.1037/ 14594-024

McLaughlin, K., \& Muldoon, O. (2014). Father identity, involvement and work-family balance: An in-depth interview study. Journal of Community \& Applied Social Psychology, 24, 439-452. http://dx.doi.org/10 1002/casp.2183

Mesmer-Magnus, J. R., \& Viswesvaran, C. (2006). How family-friendly work environments affect work/family conflict: A meta-analytic examination. Journal of Labor Research, 27, 555-574. http://dx.doi.org/10 .1007/s12122-006-1020-1

Moreira, H., Fonseca, A., Caiado, B., \& Canavarro, M. C. (2019). Workfamily conflict and mindful parenting: The mediating role of parental psychopathology symptoms and parenting stress in a sample of Portuguese employed parents. Frontiers in Psychology, 10, 635. http://dx.doi .org/10.3389/fpsyg.2019.00635

Munsch, C. L. (2016). Flexible work, flexible penalties: The effect of gender, childcare, and type of request on the flexibility bias. Social Forces, 94, 1567-1591. http://dx.doi.org/10.1093/sf/sov122

Nomaguchi, K., \& Johnson, W. (2016). Parenting stress among lowincome and working-class fathers: The role of employment. Journal of Family Issues, 37, 1535-1557. http://dx.doi.org/10.1177/0192513X 14560642

Ohu, E. A., Spitzmueller, C., Zhang, J., Thomas, C. L., Osezua, A., \& YU, J. (2019). When work-family conflict hits home: Parental work-family conflict and child health. Journal of Occupational Health Psychology, 24, 590-601. http://dx.doi.org/10.1037/ocp0000145

Palkovitz, R., Copes, M. A., \& Woolfolk, T. N. (2001). "It's like ... You discover a new sense of being:" Involved fathering as an evoker of adult 
development. Men and Masculinities, 4, 49-69. http://dx.doi.org/10 $.1177 / 1097184 X 01004001003$

Petts, R. J., \& Knoester, C. (2018). Paternity leave-taking and father engagement. Journal of Marriage and Family, 80, 1144-1162. http:// dx.doi.org/10.1111/jomf.12494

Petts, R. J., Shafer, K. M., \& Essig, L. (2018). Does adherence to masculine norms shape fathering behavior? Journal of Marriage and Family, 80, 704-720. http://dx.doi.org/10.1111/jomf.12476

Pew Research Center. (2016). Internet/broadband fact sheet. Retrieved from www.pewinternet.org

Pleck, J. H. (2010). Paternal involvement: Revised conceptualization and theoretical linkages with child outcomes. In M. E. Lamb (Ed.), The role of the father in child development (5th ed., pp. 58-93). Hoboken, NJ: Wiley.

Ramirez-Valles, J., Zimmerman, M. A., \& Juarez, L. (2002). Gender differences of neighborhood and social control processes: A study of the timing of first-intercourse among low-achieving, urban, African American youth. Youth \& Society, 33, 418-441. http://dx.doi.org/10.1177/ 0044118 X02033003004

Riina, E. M., \& Feinberg, M. E. (2012). Involvement in childrearing and mothers' and fathers' adjustment. Family Relations: An Interdisciplinary Journal of Applied Family Studies, 61, 836-850. http://dx.doi.org/ 10.1111/j.1741-3729.2012.00739.x

Smith, S. M., Roster, C. A., Golden, L. L., \& Albaum, G. S. (2016). A multi-group analysis of online survey respondent data quality: Comparing a regular USA consumer panel to MTurk samples. Journal of Business Research, 69, 3139-3148. http://dx.doi.org/10.1016/j.jbusres .2015.12.002

Terhanian, G., Bremer, J., Olmsted, J., \& Guo, J. (2016). A process for developing an optimal model for reducing bias in nonprobability sam- ples. Journal of Advertising Research, 56, 14-24. http://dx.doi.org/10 2501/JAR-2016-009

Tourangeau, R., Conrad, F., \& Couper, M. (2013). The science of web surveys. Oxford, UK: Oxford University Press. http://dx.doi.org/10 .1093/acprof:oso/9780199747047.001.0001

Tracy, S. J., \& Rivera, K. D. (2010). Endorsing equity and applauding stay-at-home moms: How male voices on work-life reveal aversive sexism and flickers of transformation. Management Communication Quarterly, 24, 3-43. http://dx.doi.org/10.1177/0893318909352248

Veneziano, R. A. (2003). The importance of paternal warmth. CrossCultural Research: The Journal of Comparative Social Science, 37, 265-281. http://dx.doi.org/10.1177/1069397103253710

Voydanoff, P. (2004). The effects of work demands and resources on work-to-family conflict and facilitation. Journal of Marriage and Family, 66, 398-412.

Weinberg, J. D., Freese, J., \& McElhattan, D. (2014). Comparing data characteristics and results of an online factorial survey between a population-based and a crowdsource-recruited sample. Sociological Science, 1, 292-310. http://dx.doi.org/10.15195/v1.a19

Williams, J. C., Blair-Loy, M., \& Berdahl, J. L. (2013). Cultural schemas, social class, and the flexibility stigma. Journal of Social Issues, 69, 209-234. http://dx.doi.org/10.1111/josi.12012

Yang, K., \& Banamah, A. (2014). Quota sampling as an alternative to probability sampling? An experimental study. Sociological Research Online, 19, 1-11. http://dx.doi.org/10.5153/sro.3199

Received September 28, 2019

Revision received March 23, 2020

Accepted April 3, 2020 